\title{
A Study of Bachelor's Degrees in Human Resource Management in Three Sri Lankan Leading State Universities
}

\author{
Opatha H. H. D. N. P. \\ Faculty of Management Studies and Commerce, University of Sri Jayewardenepura, Sri Lanka
}

Received September 16, 2019; Revised October 12, 2019; Accepted October 20, 2019

Copyright@2019 by authors, all rights reserved. Authors agree that this article remains permanently open access under the terms of the Creative Commons Attribution License 4.0 International License

\begin{abstract}
This paper pursues to explore and identify essential aspects of Human Resource Management (HRM) to be included in HRM education curriculum, to determine their sequence for right locations of HRM curriculum, to develop a framework for evaluation of quality of Bachelor's degrees in HRM, and to apply the developed framework for three cases in Sri Lanka. Being explorative and descriptive this study was carried out by using a desk research based on well-known textbooks, a survey based on the Nominal Group Technique (NGT), and an evaluative framework based on nine criteria. For the purpose of evaluation of quality of Bachelor's degree in HRM three programs were selected from three leading state universities in Sri Lanka. The results of the study generated 17 essential aspects of HRM for inclusion of HRM education curriculum. The experts' sequence of those aspects is starting with introduction to HRM and ending with sustainable HRM. And an objective evaluative framework containing nine criteria such as HRM curriculum content, appropriate location of the courses in the curriculum structure, availability of internship, duration of the internship, availability of independent study, duration of the independent study, coverage of the core skills set, availability of graduate profile, and intensity of graduate profile. The application of the objective evaluation framework resulted in revealing that the quality levels of the Bachelor's degrees of the three selected leading state universities are not at excellent rating standard implying certain areas of improvement. The results of the study may be used for curriculum development, determination of sequence of courses in the curriculum structure and enhancement of quality level of Bachelor's degrees in HRM.
\end{abstract}

Keywords Human Resource Management, HRM Education, Curriculum Development, Bachelor's Degree

\section{Introduction}

Sri Lanka, although it has a great potential, is still a developing country. She has a high level of natural beauty and certain strengths including its people some of whom are highly intelligent and promising in terms of productivity improvement and innovation. Sri Lanka has entered an era of opportunities, leaving behind the bitter times of war and destruction [1].As a nation she has been facing many challenges including organizational ones. Indeed, it is not inaccurate to mention here that Sri Lanka does not have multinational or global companies which have highly established in the international markets and the ones which can be considered as world class organizations affecting many parts of the world. Also, many employees, especially those who are highly competent, motivated, and involved have become desperate and dissatisfied with the jobs as well as the organizational works. One of the main reasons for these pathetic situations is mal-Human Resource Management (HRM) or HRM that is ineffective and insufficient. It has generally been observed that the following facts are present in Sri Lankan context:

1. HRM systems and practices being followed by a considerable number of Sri Lankan organizations are inappropriate or at least not better.

2. HRM is the most neglected field of the functional fields of organizational management in Sri Lanka.

3. Still there are organizations in which HRM is being handled by personnel who have not studied HRM formally, deeply, and scientifically.

4. There are HR managers who have not obtained a specialized higher education in HRM and it is ridiculous to notice that some of Sri Lankan HR managers are the ones with educational qualifications, 
which have nothing to do with formalized, systematic and scientific education of HRM.

5. Some of the top managers and owners of the businesses still believe in the myth that HRM can be done by using general intelligence, common knowledge, military experience or legal education.

6. Some organizations have well-developed appropriate HR systems but they are not being implemented owing to corruption, politicalization, and nepotism.

7. Teaching of HRM at some universities as well as some institutions is not based on skills development as well as not on specialized and in-depth knowledge of theory and practice of HRM.

Hence, there is a highly felt need for right graduates in HRM to work as real HRM professionals, consultants, and catalysts (who cause to establish right HRM in industries); and in this context HRM education which is right is indispensable.

HRM is a highly recognized profession in the world and it is indeed an academic discipline, which provides many solutions to create and enhance success and progress of success of organizations. Also, it cannot be forgotten that it is the field that is concerned with improving the standards of living of people at work. In order to achieve development goals of Sri Lanka, education is indispensable and HRM education is to be a top priority as it leads to create, maintain, and improve an employee workforce that mainly consists of professionals and academics specializing in HRM who are drivers of providing all the organizations with appropriate and contented workforces that give maximum individual and collective contributions to organizational success and progress of success.

Though HRM education is of very importance (it may be a rhetoric rather than a reality to authorities in the Government), surprisingly there is no any set of guidelines or a sort of standards statement issued by University Grants Commission (UGC) Sri Lanka that is the apex body for allocating government funds to the universities and issuing various rules and regulations for good governance and management of universities or Ministry of Higher Education that can be applied to design curriculum and its structure appropriately with regard to HRM education in the country. The subject benchmark statement in Management developed and issued by Quality Assurance and Accreditation Commission in Sri Lanka [2] is a useful document for academics and academic administrators engaged in HRM education but is certainly not adequate to answer the following interrelated questions:

1. What are the courses or subjects essentially to be taught in a Bachelor's degree in HRM?

2. How many courses or subjects to be taught in a Bachelor's degree in HRM?

3. What is the sequence of the courses to be taught in semesters and years within the stipulated program time period?
Another official document [3] issued by the UGC is Sri Lanka Qualification Framework (SLQE) which too does not answer the above raised questions. In order to answer the above mentioned questions there is a serious need of developing a framework that includes essential aspects of HRM, and their sequence for teaching so as to decide their sequential location of the curriculum structure. Up to the knowledge of the author no published either conceptual or empirical study has been identified in literature addressing the above mentioned questions. Hence the objectives of this study are:

1. To explore and identify essential aspects of HRM to be included in HRM education curriculum.

2. To determine the sequence of the identified essential aspects of HRM for their right locations of HRM curriculum.

3. To develop a framework for evaluation of quality of Bachelor's Degrees in HRM.

4. To evaluate three Bachelor's degrees in HRM being offered by the three leading state universities in Sri Lanka in accordance with the developed framework for evaluation.

\section{Methods}

This study is explorative and descriptive. In order to achieve the first objective, a desk research predominantly based on well-known textbooks was conducted. In order to identify essential aspects or components of the discipline of HRM a descriptive analysis of detailed contents of the textbooks considered for the study was carried out. Using at least one textbook is a generally accepted best practice in teaching a particular course or subject of a particular degree program at a recognized university. A textbook is a book containing facts about a particular subject that is used by people studying that subject [4]. For the purpose of this study, all the well-known textbooks on HRM which were available to the author were utilized. As there were several editions for some textbooks the latest edition that was available to the author was utilized for this study. Owing to space restriction only 23 textbooks which had main parts or aspects and chapters under each part/aspect were examined. These textbooks were developed by highly and appropriately qualified authors by using classic, contemporary, and relevant findings of the behavioral sciences and other related disciplines in addition to their own observations and experiences in researching and teaching. Hence stakeholder perspective was included in writing the textbooks. Majority of the textbooks were written by authors from North America and Europe. The practice of HRM dates back to several decades although its shape and systems have been determined by industrial activities in Europe and North America [5].

In order to achieve the second objective that deals with determining a sort of ideal sequencing, a popular 
technique called NGT was utilized. The NGT is regarded as a group method of drawing out ideas from a small group of experts, usually from 5 to 15 on a specific topic and it can be used for identifying reasons or aspects of an issue and prioritizing the generated items or ideas [6,7]. Compared with traditionally interacting and possibly brainstorming groups, the NGT is a technique that tends to generate more and better-quality ideas in behavioural decision making [8,9]. For the NGT under the study university professors who have many years of experience in teaching HRM and developing curriculum and courses were considered as the experts and there were 08 university professors in HRM in the state university system in Sri Lanka and all eight professors were invited. All the professors had managerial experience too and two professors in fact had worked in industry as HR professionals for several years.

Based on the results of the attempts to achieve the first and second objectives and relevant literature survey and case observation a framework for evaluation of quality of Bachelor's Degrees in HRM was developed. In case of achieving the fourth objective, three leading state universities were selected. The selection was done by using the criteria such as the history of HRM education in the university, size of the faculty, number of the enrolments, student demands for the education, international ranking, and popularity of the university in the country. The selected universities had the highest number of the students reading for Bachelor's degrees in HRM. When considered the quality level of the students these selected universities had the students who got highest marks from the university entrance examination called in Sri Lanka General Certificate of Education (Advanced Level) conducted by the Department of Examinations. Unlike private universities in Sri Lanka (few in number) there is a very high competition among the students to get enrolled for state universities in general, the selected three universities in particular. Thus, both secondary and primary data were used for this study.

\section{Essential Aspects of HRM}

HRM is concerned with the art and science of managing human resources (HR) in an organization and HRM education is concerned with gradual process by which a person gains knowledge, skills and attitude of HRM through learning. Having studied various definitions of HRM given by various authorities, Opatha [10] finds that 10 common characteristics of HRM exist and they are: HRM focuses on managing people; It is managing people at work or employees who make up an organisation; It exists within an organisation; It generally attempts to serve for the organisation where it is practiced, employees working for it and society at large; It is the human side of Business Administration; It is a traditional functional field of Business Management; It was traditionally termed as Personnel or Personnel Management; It has a set of activities that focuses on effective use of employees for the accomplishment of organisational goals; It is mainly concerned with human relationships within an organisation; and It has policies, practices and systems influencing employees. Glueck [11], who was a classic authority in HRM, presented foundations of personnel and considered the discipline as that function of all enterprises which provides for effective utilization of human resources to achieve both the objectives of the enterprise and the satisfaction and development of the employees. He viewed seven parts which included introduction to personnel; planning and personnel; recruitment, selection, and orientation; performance evaluation and development of personnel; compensation, benefits, and services; safety and health, equal employment opportunity, labor relations; and discipline, control, and evaluation. Relevant main aspects or features given by various authors in their textbooks are given in Exhibit 1. 
Exhibit 1. Aspects of HRM given by 23 Textbooks

\begin{tabular}{|c|c|c|c|}
\hline No. & Author/s & Year & Parts/Aspects/Features \\
\hline 1 & Glueck[11] & 1979 & $\begin{array}{l}\text { Introduction to personnel; Planning and personnel; Recruitment, selection, and orientation; } \\
\text { Performance evaluation and development of personnel; Compensation, benefits, and services; } \\
\text { Safety and health, equal employment opportunity, Labor relations; and discipline, control, and } \\
\text { evaluation }\end{array}$ \\
\hline 2 & Stone and Meltz[12] & 1983 & $\begin{array}{l}\text { The personnel management context; Planning and staffing; Employee development; Employee } \\
\text { maintenance; and Issues and challenges in personnel management }\end{array}$ \\
\hline 3 & Beach [13] & 1985 & $\begin{array}{l}\text { Management and the personnel field; Organization and jobs; Employment and development of } \\
\text { people; Understanding and managing people; Labor-management relations; Financial } \\
\text { compensation; Security; Employee rights; and Perspectives }\end{array}$ \\
\hline 4 & $\begin{array}{c}\text { Schuler and } \\
\text { Youngblood [14] }\end{array}$ & 1986 & $\begin{array}{l}\text { Introduction; Planning; Staffing; Appraising; Compensating; Improving; Effective working } \\
\text { relationships; and International comparisons }\end{array}$ \\
\hline 5 & $\begin{array}{l}\text { Heneman III, } \\
\text { Schwab, Fossum, } \\
\text { and Dyer[15] }\end{array}$ & 1989 & $\begin{array}{l}\text { Personnel/HRM and its environment; Individuals and jobs; Assessing personnel/HR outcomes; } \\
\text { HR planning; External staffing; Internal staffing and development; Compensation; Labor } \\
\text { relations; and Work environment }\end{array}$ \\
\hline 6 & $\begin{array}{l}\text { Bratton and } \\
\text { Gold[16] }\end{array}$ & 1994 & $\begin{array}{l}\text { The context of HRM; Planning and selection; Rewards and development; Employee and labour } \\
\text { relations }\end{array}$ \\
\hline 7 & Mamoria[17] & 1996 & $\begin{array}{l}\text { Personnel management; Employment and development of personnel; Wage and salary } \\
\text { administration; Human relations; and Employee safety, industrial health and } \\
\text { labour-management relations }\end{array}$ \\
\hline 8 & $\begin{array}{l}\text { Werther and } \\
\text { Davis[18] }\end{array}$ & 1996 & $\begin{array}{l}\text { Frameworks and challenges; Preparation and selection; Development and evaluation; } \\
\text { Compensation and protection; and Employee relations and assessment }\end{array}$ \\
\hline 9 & $\begin{array}{l}\text { Beardwell and } \\
\text { Claydon[19] }\end{array}$ & 2007 & $\begin{array}{l}\text { HRM and its organizational context including strategic aspect; Resourcing the organization; } \\
\text { Developing the HR; The employment relationship; International HRM }\end{array}$ \\
\hline 10 & $\begin{array}{l}\text { Noe, Hollenbeck, } \\
\text { Gerhart, and } \\
\text { Wright[20] }\end{array}$ & 2007 & $\begin{array}{l}\text { HRM: graining a competitive advantage; The HR environment including Strategic HRM; } \\
\text { Acquisition and preparation of HR; Assessment and development of HRM; Compensation of } \\
\text { HR; and Special topics in HRM (labor relation, managing HR globally) }\end{array}$ \\
\hline 11 & Byars and Rue[21] & 2008 & $\begin{array}{l}\text { Introduction and background of HR; Acquiring HR; Training and developing employees; } \\
\text { Compensating HR; Employee well-being; and Labor relations }\end{array}$ \\
\hline 12 & $\begin{array}{l}\text { DeNisi and } \\
\text { Griffin[22] }\end{array}$ & 2008 & $\begin{array}{l}\text { An overview of HRM; decision making in HRM; Managing the existing workforce; and } \\
\text { Enhancing performance }\end{array}$ \\
\hline 13 & Opatha[10] & 2009 & $\begin{array}{l}\text { Introduction; Employment planning; Staffing; HR development; Rewards management; } \\
\text { Employee and labour relations; and Strategic aspects of HRM }\end{array}$ \\
\hline 14 & Cascio[23] & 2010 & 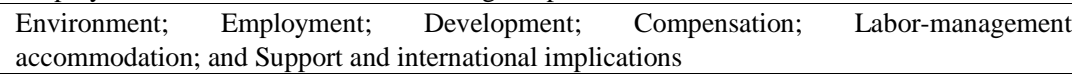 \\
\hline 15 & $\begin{array}{l}\text { Gomez-Mejia, } \\
\text { Balkin, and } \\
\text { Cardy[24] }\end{array}$ & 2010 & $\begin{array}{l}\text { Introduction; The contexts of HRM; Staffing; Employee development; Compensation; and } \\
\text { Governance }\end{array}$ \\
\hline 16 & Ivancevich[25] & 2010 & $\begin{array}{l}\text { Introduction to HRM and the environment; Acquiring HR; Rewarding HR; Developing HR; and } \\
\text { Labor-management relations and promoting safety and health }\end{array}$ \\
\hline 17 & $\begin{array}{l}\text { Mathis and } \\
\text { Jackson[26] }\end{array}$ & 2011 & $\begin{array}{l}\text { Environment of HRM; Jobs and labor; Training and Development; Compensation; and } \\
\text { Employee relations }\end{array}$ \\
\hline 18 & $\begin{array}{l}\text { Torrington, Hall, } \\
\text { Taylor, and } \\
\text { Atkinson[27] } \\
\end{array}$ & 2011 & $\begin{array}{l}\text { HRM in changing times; Resourcing: getting people in the right places to do the right things; } \\
\text { Performance: success through individual and collective achievement; Development; Employee } \\
\text { relations; Reward; Contemporary issues; and Selected HR skills }\end{array}$ \\
\hline 19 & $\begin{array}{c}\text { Jackson, Schuler, } \\
\text { and Werner[28] }\end{array}$ & 2012 & $\begin{array}{l}\text { Strategic HRM; Workforce planning and employment; HR development; Total rewards; and } \\
\text { risk management and employee relations }\end{array}$ \\
\hline 20 & $\begin{array}{l}\text { Lussier and } \\
\text { Hendon[29] }\end{array}$ & 2013 & 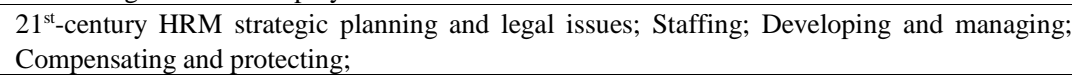 \\
\hline 21 & $\begin{array}{l}\text { Armstrong and } \\
\text { Taylor[30] }\end{array}$ & 2014 & $\begin{array}{l}\text { The practice of HRM; People and organization (including organizational behaviour); Factors } \\
\text { affecting employee behaviour; People resourcing; Learning and development; Performance and } \\
\text { reward; Employee relations; Employee well-being; and International HRM; HRM policy and } \\
\text { practice; HR skills; HRM toolkits; }\end{array}$ \\
\hline 22 & $\begin{array}{c}\text { Stewart and } \\
\text { Brown[31] }\end{array}$ & 2014 & $\begin{array}{l}\text { Setting people as a strategic resource; Securing effective employees; Improving employee } \\
\text { performance; and Motivating and managing employees; }\end{array}$ \\
\hline 23 & $\begin{array}{l}\text { Bohlander and } \\
\text { Snell[32] }\end{array}$ & 2017 & $\begin{array}{l}\text { HRM in perspective; meeting human resource requirements; Developing effectiveness in HR; } \\
\text { Implementing compensation and security; Enhancing employee-management relations; and } \\
\text { Expanding HRM horizons (global and high performance work systems) }\end{array}$ \\
\hline
\end{tabular}


As per the Exhibit it is possible to observe that there are certain aspects which have been given by almost all the authors (e.g. staffing, human resource development, and rewards or compensation). Also certain aspects (e.g. strategic, global and contemporary aspects) have been given by only some authors. A careful attempt was made to examine aspects given by all the authors mentioned in the Exhibit for identifying common aspects by avoiding repetitions. Consequently following common aspects can be listed:

1. Introduction to HRM

2. HRM context or environment (HR department, job design, job analysis, legal aspect etc.)

3. HR planning

4. Staffing or human resourcing (recruitment, selection, hiring, and induction)

5. Performance management

6. Human resource development

7. Rewards management (pay, incentives, and welfare)

8. Employee relations (safety, health, discipline, employee movements etc.)

9. Labor or industrial relations

10. Strategic aspect

11. Global or international aspect

12. Contemporary aspect

13. Human behavior

14. HR Measurement or evaluation

All textbooks numbering 23 were general in nature. Recent literature which is more specialized reveals more aspects of HRM, i.e. HR research and analytics [33,34]; e-HRM or HR information system [5,22]; and sustainable HRM [35,36,37]. All together identified aspects were 17, and these aspects were considered as evaluation criteria for the purpose of assessment of the curriculum of the bachelor's degree in HRM.

\section{Sequence of the Identified Essential Aspects/Courses of HRM}

Appropriate location of the courses in the curriculum structure refers to logical placement of courses throughout the semesters of the years in the duration of the degree program. This appropriate location of the courses is necessary for effective learning of the undergraduates. There are certain courses which need to be learnt by the undergraduates after studying some other courses. For example, a course titled International HRM needs to be learnt or needs to be offered after learning a course titled Fundamentals of HRM or Introduction to HRM. Another example is that a course titled Human Resource Development needs to be learnt after learning a course titled Staffing. In search of a right sequence of the identified essential aspects through the application of the NGT, all the professors numbering 08 were consulted and they agreed with the list of the identified essential aspects numbering 17 (they were named as course titles) and then gave their judgmental sequencing the results of which are given in Table 1.

Table 1. Results of Sequencing by Each Member

\begin{tabular}{|l|c|c|c|c|c|c|c|c|}
\hline Essential Aspect/Course Title & A & B & C & D & E & F & G & H \\
\hline Introduction to HRM & 1 & 1 & 1 & 1 & 1 & 2 & 1 & 1 \\
\hline HRM context or environment (HR department, job design, job analysis, legal aspect etc) & 2 & 2 & 2 & 3 & 2 & 3 & 2 & 2 \\
\hline HR planning & 3 & 3 & 3 & 4 & 4 & 4 & 4 & 3 \\
\hline Staffing or human resourcing (recruitment, selection, hiring, and induction) & 4 & 4 & 4 & 5 & 5 & 5 & 5 & 4 \\
\hline Performance management & 5 & 5 & 5 & 6 & 6 & 6 & 6 & 5 \\
\hline Human resource development & 6 & 6 & 6 & 7 & 7 & 7 & 7 & 13 \\
\hline Rewards management (pay, incentives, and welfare) & 7 & 7 & 7 & 8 & 8 & 8 & 8 & 6 \\
\hline Employee relations (safety, health, discipline, employee movements etc) & 9 & 8 & 8 & 9 & 9 & 9 & 9 & 7 \\
\hline Labor or industrial relations & 10 & 9 & 9 & 10 & 10 & 10 & 10 & 8 \\
\hline Strategic aspect & 11 & 17 & 12 & 2 & 11 & 11 & 11 & 15 \\
\hline Global or international aspect & $\mathbf{1 5}$ & 14 & 13 & 14 & 12 & 12 & 12 & 14 \\
\hline Contemporary aspect & $\mathbf{1 4}$ & 11 & 14 & 16 & 13 & 14 & 13 & 11 \\
\hline Human behavior & $\mathbf{8}$ & 10 & 10 & 11 & 3 & 1 & 3 & 10 \\
\hline HR Measurement or evaluation or analytics & $\mathbf{1 6}$ & 12 & 15 & 13 & 14 & 17 & 15 & 12 \\
\hline e-HRM & $\mathbf{1 2}$ & 13 & 16 & 12 & 15 & 13 & 14 & 9 \\
\hline HR Research methods & $\mathbf{1 7}$ & 15 & 11 & 17 & 16 & 16 & 16 & 17 \\
\hline Sustainable HRM (including Green HRM) & $\mathbf{1 3}$ & 16 & 17 & 15 & 17 & 15 & 17 & 16 \\
\hline
\end{tabular}

Note: Members have been identified as A, B, C, D, E, F, G, and H. 
Table 2. Determination of the Sequencing of the Essential Aspects/Courses

\begin{tabular}{|c|c|c|}
\hline Essential Aspect/Course Title & Total & Rank \\
\hline Introduction to HRM & 9 & 1 \\
\hline HRM context or environment (HR department, job design, job analysis, legal aspect etc.) & 18 & 2 \\
\hline HR planning & 28 & 3 \\
\hline Staffing or human resourcing (recruitment, selection, hiring, and induction) & 36 & 4 \\
\hline Performance management & 44 & 5 \\
\hline Human resource development & 59 & 7 \\
\hline Rewards management (pay, incentives, and welfare) & 59 & 7 \\
\hline Employee relations (safety, health, discipline, employee movements etc.) & 68 & 8 \\
\hline Labor or industrial relations & 76 & 9 \\
\hline Strategic aspect & 90 & 10 \\
\hline Global or international aspect & 93 & 11 \\
\hline Contemporary aspect & 120 & 14 \\
\hline Human behavior & 56 & 6 \\
\hline HR Measurement or evaluation or analytics & 114 & 13 \\
\hline e-HRM & 105 & 12 \\
\hline HR Research methods & 125 & 15 \\
\hline Sustainable HRM (including Green HRM) & 126 & 16 \\
\hline
\end{tabular}

Rather than giving weights, based on the total values received for each aspect/course the ranking was done. The determination of the sequencing of the essential aspects or courses is given in table 2 .

As per the table the first course to be taught is Introduction to HRM, then HRM context or environment, and finally Sustainable HRM.

\section{Framework for Evaluation of the Quality of Bachelor's Degree in HRM}

Here the working meaning of the term framework is a particular set of criteria used to deal with the issue of evaluation of quality of Bachelor's degree in HRM. The previous two sections focused on essential aspects of HRM to be included in HRM education and sequence of the identified essential aspects to be located in the curriculum structure of the Bachelor's degree in HRM. It was ascertained that these two sections' focuses involve two important variables, i.e. HRM Curriculum Content (HRM CC) and Appropriate Location of the Courses in the Curriculum Structure (ALCCS). These two variables could be considered as two criteria for evaluation and working definitions of the two criteria were developed. HRM CC refers to the extent to which the degree program structure includes the identified essential aspects or components of the discipline of HRM. ALCCS refers to logical placement of courses throughout the semesters of the years in the stipulated time period of the degree program. For a special degree the stipulated time period has four years. The first criterion was HRM CC which was considered as a variable whose level of measurement was interval with a 5-point scale that is from $5=$ all the 17 essential aspects included; $4=$ One essential aspect is missing; $3=$ two essential aspects are missing; $2=$ three essential aspects are missing; and to $1=$ more than three essential aspects are missing. The second criterion was ALCCS which too was considered as a variable whose level of measurement was interval with a 5 -point scale that is from $5=$ expert sequencing is met fully; $4=$ expert sequencing is met highly (only one is not being met); $3=$ expert sequencing is met adequately (two are not being met); $2=$ expert sequencing is not met significantly (three are not being met); and to $1=$ expert sequencing is not met highly (more than three are not being met).

As HRM is a practical field of studies it needs to develop skills in HRM with the undergraduates and consequently a major component of the Degree is to be a compulsory practical training. Work based placement or industrial training is a good standard to be followed in degree programme design and development according to University Grants Commission's manual for review of undergraduate study programmes of Sri Lankan Universities and higher education institutions. Each student will be required to embark on practical training in HRM in a private or government sector organisation for a certain period of time, for example a minimum period of six-months. This is called alternatively called as internship which is about putting the student in a real work setting in an organization. At the end of successful completion of the internship, students will be able to: acquire a practical exposure to various aspects of HRM in the actual work setting of an organization; engage in self-studies with respect of real work aspects of HRM in an organization; develop an ability to manage time and stress; and get an opportunity to contribute to enhance, in some way, the practice of HRM in the organization where the training is obtained; develop a positive attitude to real work setting. This requirement will increase the employability of the graduates and reduce the waiting time for the first job. Students may be able to get permanent jobs immediately 
after completing their practical trainings.

Independent Research Study in HRM is considered another essential requirement of the Bachelor's degree in HRM. This involves doing a research in systematic and/ or scientific way. Each student is required to write an independent research report on a selected topic in respect of HRM. The student is generally given the freedom to select a topic that he/she finds interesting and useful. If the Degree is a special degree or an honours degree, to do a research independently and write a report about it become appropriate. This requirement will build not only the ability of researching but also the ability of writing, the ability of managing time, and interpersonal ability. The student may conduct a survey, a case study, an audit-type research, an evaluative study, a causal comparative study, a desk research or any systematic study. This course is about directing the student to do a study on his or her own. Based on the above mentioned two requirements, it was possible to develop four criteria which include availability of internship, duration of the internship, availability of independent study, and duration of the independent study.

Arulrajah and Opatha [38] conducted an extensive explorative study in Sri Lanka with regard to skills required for key HRM jobs such as Director-HR, Group HR Manager, Head of HR, HR Manager, HR Executive, HR Officer, Training Manager, and Recruitment Manager. It was done by using eight selected key HRM jobs related employment advertisements appeared in the Sunday Observer (the most circulated newspaper in the country) for the period of three years. Due to exploratory nature of the study the researchers had applied population survey as an approach for data collection because it covered all the job advertisements which were related to the eight key HRM jobs during the period of the three years. Types of core skills needed to perform HRM jobs in Sri Lanka which were found from the study included 9 types such as communication and language skills, leadership skills, skills in handling computer resources or facilities, skills in arts and science of management, generalized and/or specialized skills in HRM (technical skills), skills in aligning HRM with specific business/industry operation needs, skills in dealing with people, skills in team working, and other general skills (travelling and driving). HRM technical skills, communication and language skills, leadership skills, handling skills in IT resources, and interpersonal skills were found to be as top five skills among these nine skills types. It is emphasized that a right professional in HRM must possess other skills in addition to HRM skills. As a criterion coverage of the core skills set was considered for evaluation of quality of the bachelor's degree in HRM. Figure 1 shows these nine skills types.

To have a graduate profile of the degree program is another important requirement for a successful degree program. Graduate profiles are descriptions of attributes, or knowledge, skills and attitudes, which a university community intends its graduates will develop through their study to equip them for their future education or employment; and these descriptions are written at institution and qualification level, and are used to do curriculum design as well as teaching and assessment (Massey University). A graduate profile is useful for developing curriculum and curriculum mapping processes. Table 3 presents these criteria and their measurement scales.

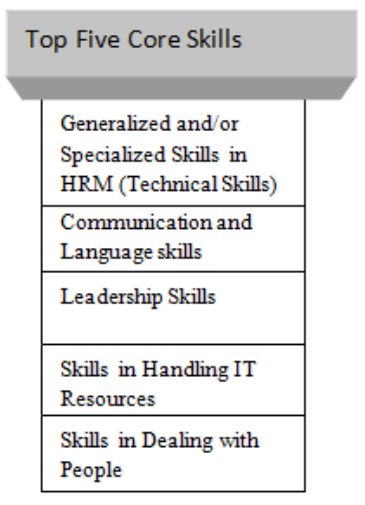

\begin{tabular}{|l|}
\hline Skills in Team Working \\
\hline $\begin{array}{l}\text { Skills in Art and } \\
\text { Science of Management }\end{array}$ \\
\hline $\begin{array}{l}\text { Skills in Aligning HRM } \\
\text { with Specific Business } \\
\text { Needs }\end{array}$ \\
\hline Other General Skills \\
\hline
\end{tabular}

Figure 1. Types of Core Skills Needed to Perform HRM Jobs in Sri Lanka

Table 3. Evaluation Criteria and their Measurement Scales

\begin{tabular}{|c|c|}
\hline Criterion & Scale \\
\hline $\begin{array}{l}\text { Availability of } \\
\text { internship/practical training }\end{array}$ & $\begin{array}{l}\text { Yes, compulsory }=05 \text { marks } \\
\text { No, optional or not offered }=01 \\
\text { mark }\end{array}$ \\
\hline Duration of the Internship & $\begin{array}{l}5=\text { A minimum of six months } \\
4=\text { Five months } \\
3=\text { Four months } \\
2=\text { Two months } \\
1=\text { One month }\end{array}$ \\
\hline $\begin{array}{l}\text { Availability of independent } \\
\text { study }\end{array}$ & $\begin{array}{l}\text { Yes, compulsory }=05 \text { marks } \\
\text { No, optional or not offered }=01 \\
\text { mark }\end{array}$ \\
\hline $\begin{array}{l}\text { Duration of the independent } \\
\text { study }\end{array}$ & $\begin{array}{l}5=\text { Five months } \\
4=\text { Four months } \\
3=\text { Three months } \\
2=\text { Two months } \\
1=\text { One month }\end{array}$ \\
\hline Coverage of the core skills set & $\begin{array}{l}5=\text { All the nine types included } \\
4=\text { One type is missing } \\
3=\text { Two types are missing } \\
2=\text { Three types are missing } \\
1=\text { More than three types are } \\
\text { missing }\end{array}$ \\
\hline Availability of graduate profile & $\begin{array}{l}\text { Yes, compulsory }=05 \text { marks } \\
\text { No, optional or not offered }=01 \\
\text { mark }\end{array}$ \\
\hline Intensity of graduate profile & $\begin{array}{l}5=\text { Knowledge, skills and } \\
\text { attitudes covered lucidly } \\
4=\text { Knowledge, skills and } \\
\text { attitudes covered } \\
3=\text { One component is missing } \\
2=\text { Two components are } \\
\text { missing } \\
1=\text { The three components are } \\
\text { missing }\end{array}$ \\
\hline
\end{tabular}




\section{Results of the Evaluation}

The developed evaluative framework consists of nine criteria, i.e. HRM curriculum content, appropriate location of the courses in the curriculum structure, availability of internship, duration of the internship, availability of independent study, duration of the independent study, coverage of the core skills set, availability of graduate profile, and intensity of graduate profile. Table 4 presents the results of the evaluation the curriculums of Bachelor's degrees in HRM offered by the three selected leading universities in Sri Lanka.

According to Table 4 the three selected universities' programs received scores 3,2 , and 3 respectively out of a maximum of 5 . Table 5 presents the results of the evaluation done by using all the nine criteria with regard to the Bachelor's degrees in HRM offered by the three selected leading universities in Sri Lanka.

Table 4.Evaluation of the Curriculums of Bachelor's Degrees in HRM offered by the Three Selected Leading Sri Lankan Universities in terms of HRM Curriculum Content

\begin{tabular}{|c|l|c|c|c|}
\hline No. & Essential Aspect & University A & University B & University C \\
\hline 1 & Introduction to HRM & Included & Included & Included \\
\hline 2 & $\begin{array}{l}\text { HRM context or environment (HR department, job design, job analysis, legal } \\
\text { aspect etc.) }\end{array}$ & Included & Included & Included \\
\hline 3 & HR planning & Included & Included & Included \\
\hline 4 & Staffing or human resourcing (recruitment, selection, hiring, and induction) & Included & Included & Included \\
\hline 5 & Performance management & Included & Included & Included \\
\hline 6 & Human resource development & Included & Included & Included \\
\hline 7 & Rewards management (pay, incentives, and welfare) & Included & Included & Included \\
\hline 8 & Employee relations (safety, health, discipline, employee movements etc.) & Included & Included & Included \\
\hline 9 & Labor or industrial relations & Included & Included & Included \\
\hline 10 & Strategic aspect & Included & Included & Included \\
\hline 11 & Global or international aspect & Included & Not included & Included \\
\hline 12 & Contemporary aspect & Included & Included & Not included \\
\hline 13 & Human behavior & Included & Included & Included \\
\hline 14 & HR Measurement or evaluation or analytics & Not included & Not included & Included \\
\hline 15 & e-HRM & Included & Included & Included \\
\hline 16 & HR Research methods & Included & Included & Included \\
\hline 17 & Sustainable HRM (including Green HRM) & Not included & Not included & Not included \\
\hline & Number of essential aspects not included & 3 & 3 & 2 \\
\hline & Score awarded & 2 & 3 \\
\hline
\end{tabular}

Note: To secure 'included', the aspect has to be offered as a core or compulsory course, not as an optional one.

Table 5.Evaluation of the Curriculums of Bachelor's Degrees in HRM offered by Three Leading Sri Lankan Universities in terms of the Nine Criteria

\begin{tabular}{|c|c|c|c|c|}
\hline No. & Criterion & University A & University B & University $\mathbf{C}$ \\
\hline 1 & HRM curriculum content & 3 & 2 & 3 \\
\hline 2 & Appropriate location of the courses in the curriculum structure & 3 & 2 & 2 \\
\hline 3 & Availability of internship & 5 & 5 & 5 \\
\hline 4 & Duration of the internship & 5 & 5 & 5 \\
\hline 5 & Availability of independent study & 5 & 5 & 5 \\
\hline 6 & Duration of the independent study & 5 & 5 & 5 \\
\hline 7 & Coverage of the core skills set & 5 & 5 & 5 \\
\hline 8 & Availability of graduate profile & 5 & 1 & 1 \\
\hline 9 & Intensity of graduate profile & 3 & - & - \\
\hline 10 & Total scores awarded & 39 & 30 & 31 \\
\hline 11 & Mean score & 4.3 & 3.3 & 3.4 \\
\hline 12 & Descriptive rating given & Good & Satisfactory & Satisfactory \\
\hline
\end{tabular}

Note: The type of other skills was not considered under criterion 7 as that is beyond the university education. 
According to the results of evaluation given in Table 5, the three universities were given with mean scores 4.3, 3.3, and 3.4 respectively. The university A got the highest mean and the other two universities got the same approximately. However, there is a room for improvement for each university. Two main criteria, i.e. HRM curriculum content and appropriate location of the courses in the curriculum structure need to be improved with regard to Bachelor's degrees in HRM offered by all the three universities. Two universities do not have the graduate profile. Although university A has the graduate profile its intensity is not very high or high. One component, i.e. attitude is missing.

\section{Discussion and Conclusions}

As there are no previous similar studies being available to the researcher, there is no possibility of making a traditional type of discussion to confirm the research findings through the previous empirical research evidence. Curriculum is a critical factor in student academic success; and comprehensive, content-rich curriculum is a common feature of academically high-performing countries [39].The first objective of this study was to explore and identify essential aspects of HRM to be included in HRM education curriculum. The desk research based on 23 well-known textbooks was carried out and 17 essential aspects were identified. These aspects can be considered as courses to be taught in HRM education and some courses are generalized and others are specialized. Essential aspects such as introduction to HRM, HRM context, and human behavior are generalized courses while all other essential aspects are specialized ones. Both generalized understanding and specialized understanding are required for a person who is supposed to be a successful professional in HRM. Each identified essential aspect has certain issues in managing people at work. A Bachelor's degree can be a general degree or a special degree (alternatively identified as an honors degree). In the Sri Lankan university system, all the Bachelor's degrees in the various fields of Business Administration being offered by state universities are special degrees with 4-year duration. Each year has two semesters and all together eight semesters for the four years. In this context it is very important to have an appropriate sequence of the identified aspects of HRM for the right locations of the HRM curriculum. Curriculum development process is generally done by experts [40].The second objective of the study was in this regard. Application of the NGT resulted in a sequence as given in Table 2 according to which the first aspect to be taught is introduction to HRM and the final aspect is sustainable HRM including green HRM. Essential aspects such as HR planning, staffing, performance management, human resource development, rewards management, employee relations, and labor relations which are specialized courses that need to be offered or taught in the middle stage of educating undergraduates, i.e. in the second year and the third year. Essential aspects such as strategic, global and contemporary need to be placed at the final stage of educating, i.e. in the final year.

Third objective of this study was to develop a framework for evaluation of quality of Bachelor's degrees in HRM. It is generally accepted that without criteria no meaningful evaluation can be performed. Based on the results of the previous two attempts done under this study and literature review nine criteria for evaluation purpose were found and they include HRM curriculum content, appropriate location of the courses in the curriculum structure, availability of internship, duration of the internship, availability of independent study, duration of the independent study, coverage of the core skills set, availability of graduate profile, and intensity of graduate profile. These criteria are objective rather than subjective as they are relatively easy to define, quantify, and verify. Hence the developed evaluation framework is an objective one rather than a subjective one. According to SLQE Bachelors Honours comes under level 6 and minimum volume of learning required for each level 120 credits (one credit is equal to 45 hours of direct teaching). According to the same, the research component should not be less than a total of at least 6 credits. These and other (not mentioned here) standards were not considered in the evaluation done in this study. The reason is that currently all the bachelor's degrees offered by all the state universities in Sri Lanka need to be adhered to the SLQE standards and therefore they do not become comparative criteria.

The fourth objective of this study was to evaluate three Bachelor's degrees in HRM being offered by the three leading state universities in Sri Lanka in accordance with the developed framework for evaluation. The result of evaluation revealed that the university A got the highest mean and the other two universities got the same approximately. Based on mean values, none of the three programs can be rated as excellent. Only the program being offered by university A was rated as good and other two programs offered by university B and university C were rated as satisfactory. An implication is that a significant need of improving the quality of the programs exists. A particular attention has to be drawn to HRM curriculum content and appropriate location of the courses in the curriculum structure. Furthermore a graduate profile is recommended to be developed for the two universities which do not have it. Although university A has the graduate profile one component, i.e. attitude component is missing. Hence its intensity is moderate, not very high or high implying a room for improvement. It should be noted that the evaluation of the quality of the bachelor's degrees in HRM was done with the intention of improving the status quo rather than demeaning their status. It is believed that the identified 17 essential aspects of HRM are useful for inclusion of HRM education curriculum. The determined sequence of the seventeen essential aspects will 
be instrumental in right structuring of the curriculum. The evaluative framework which was developed by using nine objective criteria will be a contribution to the existing body knowledge of HRM education. The results of the evaluation of the three cases are expected to be useful for decision makers to do quality enhancement of the Bachelor's degrees in HRM. It is recommended that HRM curriculum and appropriate location of the courses in the curriculum structure of all the three universities, particularly university $\mathrm{B}$ and university $\mathrm{C}$ need to be improved based on the findings relating to the objectives 1 and 2. As graduate profile is not available in two HRM degree programs and also the intensity of the graduate profile available in one HRM degree program evaluated is not at the level "knowledge, skills and attitudes covered lucidly", a model graduate profile is proposed and it has been presented in the Appendix. Enriched HRM education remains a veritable means of nation building in Sri Lanka and it is not inaccurate to mention here that other resources make things possible but only human resources make things happen.

\section{Appendix: A Model Graduate Profile for Bachelor's Degree in HRM}

\section{ABC University HRM GRADUATE PROFILE}

On successful completion of the Degree BSc Human Resource Management (Special), graduates should be able to acquire knowledge, skills, and attitudes addressing seven broad domains of capabilities which are: (1) HRM Discipline Capability, (2) General Management Capability, (3) Human Relations Capability, (4) Information Technology Capability, (5) Communication Capability, (6) Personal Management capability, and (7) Personal Quality Enhancement Capability. The Department of HRM of ABC University considers the above mentioned seven capabilities to be attainable by graduates in HRM. A Human Resource Management Graduate will have the following attributes, or knowledge, skills and attitudes (these are the set of attributes the department of HRM of $\mathrm{ABC}$ University seeks and endeavours to impart to, or foster in, its graduates):

\section{Knowledge (HRM GRADUATES KNOW. THEY):}

1. Demonstrate generalized knowledge of various functions of HRM.

2. Demonstrate specialized understanding of core fields of HRM such as employment planning, staffing, human resource development, rewards management, and employee and labour relations.

3. Have knowledge of various soft aspects of HRM including human relations, and psychological thinking, theory and practice.

4. Possess knowledge of contemporary, international, strategic and sustainable aspects of HRM.
5. Have an adequate knowledge of general aspects of managing an organization, and other functional fields of organizational management.

6. Demonstrate know-how of followership and leadership through proper communication, information technology and interpersonal dealings.

7. Possess knowledge of morality enhancement, ethical and social performance, and self-management.

\section{Skills (HRM GRADUATES DO. THEY):}

1. Apply fundamental concepts and principles of HRM in solving cases and critical incidents.

2. Develop practical schemes or programmes (which include appropriate policies, procedures, rules etc.) in solving traditional and non-traditional issues in HRM.

3. Originate reviews, evaluations or audits of actual HRM practices and propose remedial actions and initiatives to enhance the practice of HRM in organizational settings.

4. Perform a systematic, and/ or scientific investigation into a HRM phenomenon so as to solve an existing problem, or enhancing the existing level of that phenomenon, or provide useful information to enhance the quality level of practice.

5. Evaluate the legal, social, economic and other environments and apply knowledge of business functions in an appropriate manner and an integrated manner in organizational settings.

6. Apply knowledge of communication, IT, and interpersonal dealings to work effectively in teams, in followership, and in leading.

7. Perform gap analyses in order to identify weaknesses or areas of improvement, learning with regard to identified weaknesses or areas of improvement, and reviews for progress of building critical observable behaviours, in particular with regard to personal quality enhancement, personality development and self-management.

\section{Attitudes (HRM GRADUATES BELIEVE, FEEL, AND} TEND TO BEHAVE. THEY):

1. Believe that institutional development and human development heavily depend on HRM.

2. Believe that all the problems of organizations can at least partially be solved by sound HRM.

3. Demonstrate appreciation for human resources as the most important resource an organization has when compared with all other resources.

4. Show intention to become a person who is capable, motivated and committed to work in managing human resources.

5. Believe that it is possible to lead a very successful life by working in the field of HRM, and or Management.

6. Show behavioural tendency to become a successful follower and a successful leader.

7. Exhibit a strong feeling interestingly and positively with regard to becoming a person of morality, ethics and responsibility. 


\section{REFERENCES}

[1] S. Ranasinghe, A. Dharmasiri. HR Challenge, the Institute of Personnel Management Sri Lanka, Colombo, 2013.

[2] Quality Assurance and Accreditation Council, University Grants Commission Sri Lanka, Subject Benchmark Statement in Management, Colombo, 2010.

[3] University Grants Commission Sri Lanka, Sri Lanka Qualification Framework, Colombo, 2015.

[4] The Collins Birmingham University English Language Dictionary, 1987.

[5] V. Benuyenah, B. Boukareva. Making HRM curriculum relevant- a hypothetical practitioners' guide, Journal of world-Applied Management, Vol.10, No.1, 93-100.

[6] B.W. Werther, K. Davis, H.F. Shwind, H. Das, F.C. Miner.Canadian Personnel Management and Human Resources, Mcgraw-Hill Reversion Ltd, Toronto, 1985.

[7] S.L. McShane, M.A.V. Glinow, R.R. Sharma, Organizational Behaviour, McGraw-Hill, New York, 2008.

[8] H. Barki, A. Pinsonneault. Small Group Brainstorming and Idea Quality, Small Group Research, Vol. 32, No. 2, 158-205.

[9] S. Frankel. An adaptation of nominal group technique for ill-structured problems, Journal of Applied Behavioral Science, Vol. 23, No. 5, 543-551.

[10] H.H.D.N.P. Opatha. Human Resource Management, Department of HRM, University of Sri Jayewardenepura, Colombo, 2009.

[11] W.F. Glueck. Foundations of Personnel, Business Publications Inc, Texas, 1979.

[12] T.H. Stone, N.M. Meltz. Personnel Management in Canada, Holt, Rinehart and Winston of Canada Ltd, Toronto, 1983.

[13] D.S. Beach. Personnel: The Management of People at Work, Macmillan Company, New York, 1985.

[14] R.S. Schuler, B.S.A. Youngblood. Effective Personnel Management, West Publishing Company, New York, 1986.

[15] H.G. Heneman III, D.P. Schwab, J.A. Fossum, L.D. Dyer. Personnel/Human Resource Management, Richard D. Irwin, Inc, New York, 1989.

[16] J. Bratton, J. Gold. Human Resource Management: Theory and Practice, Macmillan, London, 1994.

[17] C. Mamoria. Personnel Management, Himalaya Publishing House, Bombay, 1996.

[18] B.W. Werther, K. Davis. Human Resources and Personnel Management, McGraw-Hill Book Company, New York, 1989.

[19] J. beardwell, T. Claydon. Human Resource Management: A Contemporary Approach, Prentice Hall, London, 2007.

[20] R.A. Noe, J.R. Hollenbeck, B. Gerhart, P.M. Wright. Human
Resource Management, Tata McGraw-Hill Publishing Company ltd (Indian Print), New Delhi, 2007.

[21] L.L. Byars, L.W. Rue. Human Resource Management, McGraw-Hill Irwin, Boston, 2008.

[22] A. S. DeNisi, R.W. Griffin. Human Resource Management, South-Western CENGAGE Learning, Mason, 2008.

[23] W.F. Casio. Managing Human Resources: Productivity, Quality of Work Life, Profits, McGraw-Hill Irwin, Boston, 2010.

[24] L.R. Gomez-Mejia, D.B. Balkin, R.L. Cardy. Managing Human Resources, Prentice Hall, Boston, 2010.

[25] J.M. Ivancevich, Human Resource Management, McGraw-Hill Irwin, Boston, 2010.

[26] R.L. Mathis, J.H. Jackson. Human Resource Management, South-Western CENGAGE Learning, Mason, 2011.

[27] D.T. Torrington, L. Hall, S. Taylor, C. Atkinson. Human Resource Management, PEARSON, London, 2011.

[28] S.E. Jackson, R.S. Schuler, S. Werner. Managing Human Resources, South-Western CENGAGE Learning, Mason, 2012.

[29] R.N. Lussier, J.R. Hendon. Human Resource Management: Functions, Applications, Skill Development, SAGE, Los Angeles, 2013.

[30] M. Armstrong, S. Taylor. Armstrong’s Handbook of Human Resource Management, Kogan Page, London, 2014.

[31] G.L. Stewart, K.G. Brown. Human Resource Management: Linking Strategy to Practice, WILEY, New York, 2014

[32] G. Bohlander, S. Snell. Principles of Human Resource Management, CENGAGE Learning, Mason, 2017.

[33] D.K. Bhattacharyya. HR Analytics, SAGE, Los Angeles, 2017.

[34] S. VanWieren. Quantifiably Better Delivering HR Analytics from Start to Finish, Technics Publications, 2017.

[35] S. Ahmad. Green Human Resource Management: Policies and Practices, Cogent Business and Management, Vol. 2, No. 1030817 http://dx.doi.org/10.1080/23311975.2015.10 30817

[36] Z. Stankevicite, A. Savanevicine. Designing sustainable HRM: The core characteristics of emerging field, Sustainability, Vol.10, No. 4798, 1-23.

[37] H.H.D.N.P. Opatha. Sustainable Human Resource Management: Expanding Horizons of HRM, Department of HRM, University of Sri Jayewardenepura, Colombo, 2019.

[38] A. Arulrajah, H.H.D.N.P. Opatha. Skills required for key HRM jobs in Sri Lanka: an explorative study of newspaper advertisement, Wayamba Journal of Management, Vol.1, No. 2, 76-87.

[39] D. Steiner. Curriculum Research: What We Know and Where We Need to Go, Standards Work, 2017.

[40] H.H. Ozkan. An Analysis of Teachers' Opinions about Their Knowledge of Curriculum Terms Awareness, Universal Journal of Educational Research, Vol. 4, No. 7, 1601-1613. 